\title{
The fructokinase from Rhizobium leguminosarum biovar trifolii belongs to group I fructokinase enzymes and is encoded separately from other carbohydrate metabolism enzymes
}

\author{
George J. Fennington, Jr and Thomas A. Hughes \\ Author for correspondence: Thomas A. Hughes. Tel: +1803656 3057. Fax: +18036561127.
}

Department of

Microbiology, Clemson

University, Clemson, South

Carolina 29634-1909, USA

\begin{abstract}
The Rhizobium leguminosarum bv. trifolii BAL fructokinase (frk) gene was isolated on a $2.4 \mathrm{~kb}$ BamHI fragment from the cosmid pLA72 by complementation analysis of the Tn5-induced frk mutant BAL79, and confirmed by hybridization analysis. The nucleotide sequence of the frk gene was found to contain an open reading frame consisting of 978 bp encoding 326 amino acids, which was then compared to known fructokinase sequences. The fructokinase gene was not contained in an operon and is encoded separately from other enzymes of carbohydrate metabolism. Its product is therefore assigned to the group I fructokinases. A putative promoter (TTGACA- $\mathbf{N}_{16}$ GTTGAT), ribosome-binding site and termination sequence were identified. The Frk protein contained several motifs conserved in other known fructokinase sequences, including an ATP-binding and a substrate-binding motif. The hydropathy plot derived from the frk gene sequence data revealed the fructokinase as a hydrophilic protein. The fructokinase protein was purified to electrophoretic homogeneity by a three-step method using chromatofocusing, affinity chromatography and gel filtration. Its purity was confirmed by SDSPAGE and it was visualized as a single band by silver staining. The $\mathbf{N}$-terminal amino acid sequence of the purified fructokinase confirmed the proposed open reading frame of the frk gene. The purified fructokinase had a molecular mass of $36.5 \mathrm{kDa}$, pl of 4.65, pH activity range of 6.0-9.0 (maximum activity at pH 8.0) and a $\mathrm{Mg}^{2+}$ requirement. It had a $K_{\mathrm{m}}$ of $0.31 \mathrm{mM}$ and a $V_{\max }$ of $31 \mu \mathrm{mol}$ fructose 6-phosphate (mg protein) ${ }^{-1} \mathrm{~min}^{-1}$ with fructose as substrate. The $R$. leguminosarum bv. trifolif BAL fructokinase was biochemically and molecularly similar to other bacterial fructokinases.
\end{abstract}

Keywords: Rbizobium leguminosarum bv. trifolii, fructokinase, sequence analyis

\section{INTRODUCTION}

Carbohydrate supply is a major limiting factor in nitrogen fixation by Rhizobium-legume symbioses (Bethlenfalvay \& Phillips, 1977; Pate, 1977). Sucrose is the major product of photosynthesis translocated to the nodule (Bach et al., 1958) and fructokinase is a key enzyme in the metabolism of sucrose (as well as mannitol and fructose) in Rhizobium, catalysing the phosphorylation of fructose to fructose 6-

Abbreviation: TCA, tricarboxylic acid.

The GenBank accession number for the sequence reported in this paper is U08434. phosphate (Martinez deDrets \& Arias, 1970). It is induced by the inclusion of these substrates in the growth medium (McLaughlin \& Hughes, 1989; Ronson \& Primrose, 1979 ) and repressed by TCA cycle intermediates (Stowers \& Elkan, 1985). Transposon-induced mutants defective in fructokinase have been isolated in several Rhizobium species (Glenn et al., 1984; Duncan, 1981; McLaughlin \& Hughes, 1989), and a fre mutant of R. leguminosarum bv. trifolii BAL was unable to grow on mannitol or fructose and its growth on sucrose was impaired. The frk mutant, BAL79, failed to produce polysaccharide capsule on complex or minimal media containing mannitol (McLaughlin \& Hughes, 1989). 
Fructokinase genes have been sequenced from a number of bacteria, including Escherichia coli, Salmonella typhimurium, Klebsiella pneumoniae, Vibrio alginolyticus, Streptococcus mutans and Zymomonas mobilis, but not to our knowledge from any Rhizobium species (Aulkemeyer et al., 1991; Blatch et al., 1990; Brockman et al., 1992; Sato et al., 1993; Zembrzuski et al., 1992). These fructokinase genes, designated $s c r K$, are commonly found in an operon involved in sucrose utilization. In $K$. penumoniae and $S$. typhimurium (pUR400), scrK is the first gene of a transcriptional unit, scrKAYBR, which includes the genes for the membrane porin $(\operatorname{scr} Y)$, sucrase $(\operatorname{scr} A)$, sucrose-6-phosphate hydrolase $(s c r B)$ and the repressor, $s c r R$ (Aulkemeyer et al., 1991; Blatch \& Woods, 1991). Jahreis \& Lengeler (1993) identified D-fructose and fructose 6phosphate as the inducer molecules for the sucrose utilization operon and a repressor has been identified, ScrR, which binds directly to a palindromic operator sequence. Previously, the fructokinase gene from $Z$. mobilis was shown to be the only exception, as it is not transcriptionally linked to an operon and is proposed to be involved specifically in fructose and not sucrose utilization. The $Z$. mobilis enzyme is classed as a group I fructokinase; the fructokinases involved in sucrose utilization are classed as group II (Zembrzuski et al., 1993).

Rhizobium leguminosarum bv. trifolii BAL produces numerous nodules and infection threads on its host Trifolium repens, white clover (Dazzo \& Hubble, 1975). McLaughlin \& Hughes (1989) isolated the fructokinase gene from $R$. leguminosarum bv. trifolii by complementation of the $\operatorname{Tn} 5$ induced frk mutant BAL79 with the cosmid pLA72. The frk mutant was still able to nodulate white clover and fix nitrogen (McLaughlin \& Hughes, 1989). Using subcloning and complementation of the frk mutant BAL79, the frk gene was isolated on a $2 \cdot 4 \mathrm{~kb} \mathrm{BamHI}$ fragment and used for nucleotide sequence analysis.

This study reports the nucleotide sequence of the fructokinase ( $f r k$ ) gene from R. leguminosarum bv. trifolii BAL, the deduced amino acid sequence and similarities to other known fructokinases. The fructokinase enzyme was purified to electrophoretic homogeneity and partially characterized. In addition, the N-terminal amino acid sequence of the fructokinase protein was determined, thus confirming the reported gene sequence.

\section{METHODS}

Bacterial strains, media and culture conditions. Bacterial strains and plasmids used in this work are listed in Table 1. Rbizobium leguminosarum bv. trifolii strains were grown on yeast extract mannitol medium (YEM; Vincent, 1970) at $30^{\circ} \mathrm{C}$. Escherichia coli strains were grown as described by Maniatis $e t$ al. (1989) in Luria broth. Mutants and plasmid-containing strains were supplemented with the appropriate antibiotic: tetracycline $\left(12.5 \mu \mathrm{g} \mathrm{ml}^{-1}\right.$ for $E$. coli and $\mathrm{R}$. leguminosarum), and kanamycin $\left(50 \mu \mathrm{g} \mathrm{ml}^{-1}\right.$ for $E$. coli and $150 \mu \mathrm{g} \mathrm{ml}^{-1}$ for $\mathrm{R}$. leguminosarum) (Table 1). For solid medium $15 \mathrm{~g}_{\text {agar }} \mathrm{l}^{-1}$ was added.

Subcloning and complementation of the frk gene. Cosmid DNA, pLA72, was isolated by the alkaline extraction method and purified by $\mathrm{CsCl}_{2}$ density-gradieni ultracentrifugation (Maniatis et al., 1989). Partial digestion with Sau3A was performed using the dilution method (Maniatis et al., 1989) and fragments were purified by the GeneClean procedure (Bio 101). The Sau3A-digested cosmid DNA was ligated into the Bam HI site of pRK404 (Ditta et al., 1985) and ligated at $16^{\circ} \mathrm{C}$ for $24 \mathrm{~h}$ (Maniatis et al., 1989) using T4 ligase. Ligation mixtures were transformed into E. coli DH5 $\alpha$ using the method of Hanahan (1983). DNA inserts were verified on Luria agar containing $0 \cdot 1 \mathrm{mM}$ IPTG, $0 \cdot 04 \% \mathrm{X}-\mathrm{Gal}$ and tetracycline $\left(12.5 \mu \mathrm{g} \mathrm{ml}^{-1}\right)$. Plasmids were transferred to $R$. leguminosarum bv. trifolii by triparental mating (Ditta et al., 1980). Complementation of the frk gene was analysed by isolation of the recipient transconjugant colonies on YEM-K'T agar (YEM plus kanamycin and tetracycline; McLaughlin \& Hughes, 1989).

Southern gel analysis and hybridization conditions. Total DNA was isolated and Southern blot analysis done by standard procedures (Maniatis et al., 1989; Southern et al., 1975), using the $2.4 \mathrm{~kb}$ fragment containing the frk gene as a probe. The probe was labelled with biotin-11-dUTP using the Nick Translation Kit from BRL. Hybridizations were done at $42^{\circ} \mathrm{C}$, with $45 \%(\mathrm{v} / \mathrm{v})$ formamide, using the solutions and washes as recommended by the manufacturer for biotinylated probes (Leary et al., 1983). Hybridizations were visualized using the BluGene Nonradioactive Nucleic Acid Detection System (BRL).

Subclone analysis and DNA sequencing. The $2.4 \mathrm{~kb}$ fragment was subcloned into the BamHI site of pBluescriptSK (Stratagene). Restriction mapping was performed by standard procedures (Maniatis et al., 1989). E. coli subclones for sequencing were screened for fructokinase activity (Martinez deDrets \& Arias, 1970; Sato et al., 1993) and plasmid DNA for sequencing was prepared using the Plasmid Midi Kit (Qiogen). Sequencing was done by the dideoxy chain-termination method (Sanger et al., 1977), using Taq DNA polymerase (Promega) with the DyeDeoxy Terminator Cycle Sequencing Kit (Applied Biosystems) and a thermocycler (Perkin Elmer Cetus). Reaction mixtures were purified on a CentraSep spin column (Princeston Separations) and dried in a Speed Vac (Savant Instruments). An automated DNA sequencer (Applied Biosystems, model 373A) was utilized to determine the nucleotide sequence of both strands of the entire $2.4 \mathrm{~kb}$ fragment. Analysis of overlapping and complementary sequence data was performed on a Macintosh SE/30 using the Gene Jockey program (Biosoft). Sequence analysis was performed at the NCBI using the BLAST network service (Devereux et al., 1984).

Enzyme assay conditions. Fructokinase activity was determined spectrophotometrically at $25^{\circ} \mathrm{C}$ by the method of Martinez deDrets \& Arias (1970). The enzyme assay mixture contained (1 ml total volume): $40 \mathrm{mM}$ fructose, $2 \mathrm{mM}$ ATP, $1 \mathrm{mM}$ NADP, $5 \mathrm{mM} \mathrm{MgCl} 2 \cdot \mathrm{H}_{2} \mathrm{O}, 1 \mathrm{U}$ phosphoglucose isomerase, $1 \mathrm{U}$ glucose-6-phosphate dehydrogenase, and $75 \mu \mathrm{l}$ enzyme extract. Fructokinase activity was determined at various $\mathrm{pH}$ values using the enzyme assay as described except that the $\mathrm{pH}$ of the reaction mixture was adjusted with $0.5 \mathrm{M}$ Tris/ $\mathrm{HCl}$ to range from 6.0 to $9 \cdot 0$. Divalent cation requirements were determined by substituting the $\mathrm{MgCl}_{2}(1 \mathrm{mM})$ in the fructokinase assay reaction mixture with an equal molar amount of various other cations (Thompson et al., 1991). The $K_{\mathrm{m}}$ and $V_{\max }$ were determined according to the method of Lineweaver \& Burke (1934). Protein was determined by the dye binding method of Bradford (1976).

\section{Enzyme purification}

Step 1. Extraction and centrifugation. Cells of R. leguminosarum bv. trifolii (1 l) were harvested by centrifugation ( 800 r.p.m. for $15 \mathrm{~min}$ ) and resuspended in distilled water containing $1 \mathrm{mM}$ DTT. The cells were disrupted by two passages through a 
Table 1. Bacterial strains and plasmids

\begin{tabular}{|c|c|c|}
\hline Strain or plasmid & Relevant characteristics* & Reference or source \\
\hline \multicolumn{3}{|l|}{ Strains } \\
\hline \multirow{2}{*}{\multicolumn{3}{|c|}{$\begin{array}{l}\text { R. leguminosarum } \\
\text { bv. trifolii }\end{array}$}} \\
\hline & & \\
\hline BAL & Wild-type & Dazzo \& Hubbel (1975) \\
\hline BAL 79 & Frk $^{-}\left[\right.$frk:: $\left.\operatorname{Tn} 5\left(\mathrm{Kan}^{\mathrm{r}} / \mathrm{Str}^{\mathrm{r}}\right)\right]$ & McLaughlin \& Hughes (1989) \\
\hline BAL C79 & Frk $^{+}\left[\right.$BAL 79/pLA72('Tet $\left.\left.{ }^{r}\right)\right]$ & McLaughlin \& Hughes (1989) \\
\hline BAL B30 & $\mathrm{Frk}^{+}\left[\mathrm{BAL} 79 / \mathrm{pB} 30\left(\mathrm{Tet}^{\mathrm{r})}\right)\right]$ & This report \\
\hline \multicolumn{3}{|l|}{ E. coli } \\
\hline HB101 & $\mathrm{F}^{-}$, bsdS20 rec $A$ ara pro $\mathrm{Str}^{\mathrm{r}}$ & Maniatis et al. (1982) \\
\hline $\mathrm{DH} 5 \alpha$ & 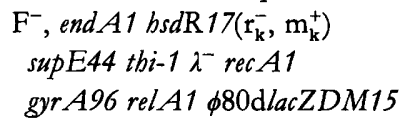 & BRL \\
\hline \multicolumn{3}{|l|}{ Plasmids } \\
\hline pRK404 & Tet $^{r}$, ori $T$ oriV lac $Z$ & Ditta et al. (1985) \\
\hline pRK2013 & $\operatorname{Kan}^{r}$, oriT tra & Ditta et al. (1980) \\
\hline pLA72 & $\operatorname{Tet}^{\mathrm{r}}, f_{r k}{ }^{+}$ & McLaughlin \& Hughes (1989) \\
\hline pBluescriptSK & $A m p r, ~ l a c Z, T 3, T 7$ & Stratagene Cloning Systems \\
\hline $\mathrm{pB} 12$ & $\mathrm{Tet}^{\mathrm{r}}$, frk $^{+}$oriV & This report \\
\hline $\mathrm{pB} 30$ & $\mathrm{Tet}^{\mathrm{r}}$, frk $k^{+}$oriV & This report \\
\hline $\mathrm{pB} 40$ & $\mathrm{Tet}^{\mathrm{r}}$, frk $^{+}$oriV & This report \\
\hline pBSK12 & $\mathrm{Amp}^{\mathrm{r}}, f r k^{+} l a c Z, \mathrm{~T} 3, \mathrm{~T} 7$ & This report \\
\hline
\end{tabular}

*Frk, fructokinase; Tet ${ }^{\mathrm{r}}$, tetracycline resistance $\left(12.5 \mu \mathrm{g} \mathrm{ml}^{-1}\right.$ for E. coli and R. leguminosarum bv. trifolii); $\mathrm{Kan}^{\mathrm{r}}$, kanamycin resistance $\left(50 \mu \mathrm{g} \mathrm{m}^{-1}\right.$ for E. coli and $150 \mu \mathrm{g} \mathrm{ml}^{-1}$ for R. leguminosarum bv. trifolii); Str ${ }^{\mathrm{r}}$, streptomycin resistance $\left(50 \mu \mathrm{g} \mathrm{ml}^{-1}\right.$ for $E$. coli and $R$. leguminsarum bv. trifolii); ori $V$, origin of replication from RP4; ori $T$, origin of transfer from RP4; lac $Z$, lac $Z$ cloning region; $T 3$ and $T 7$, primer regions.

French pressure cell at 1260 p.s.i. $(8 \cdot 7 \mathrm{MPa})$ and centrifuged at 16000 r.p.m. for $30 \mathrm{~min}$. The supernatant was used as the cellfree extract.

Step. 2. Chromatofocusing. Cell-free extract was dialysed overnight at $4{ }^{\circ} \mathrm{C}$ in $25 \mathrm{mM}$ histidine buffer ( $\mathrm{pH} \mathrm{6.0)} \mathrm{containing}$ $1 \mathrm{mM}$ DT'T. Sucrose was added to a final concentration of $0.5 \%$ and the mixture was loaded onto a column $(2.8 \times 50 \mathrm{~cm})$ containing polybuffer exchanger PBE94 (Pharmacia) equilibrated with histidine buffer. Samples were eluted using polybuffer 74 ( $\mathrm{pH} \mathrm{4 \cdot 0)}$ according to the method of Lallan (1990). Fractions containing enzyme activity were pooled and dialysed against 11 affinity column buffer ( $1 \mathrm{mM}$ MOPS $\mathrm{pH} \mathrm{7.0}$ containing $1 \mathrm{mM} \mathrm{MgCl}$ and $1 \mathrm{mM} \mathrm{DTT}$ ). Dialysis was monitored by change in $\mathrm{pH}$.

Step 3. Affinity chromatography. The column matrix was constructed by the method of Vretblad (1976) by mixing $1 \mathrm{~g}$ epoxyactivated agarose (Sigma) and $250 \mathrm{mg}$ D-fructose with $100 \mathrm{ml}$ distilled water for $16 \mathrm{~h}$ at $25^{\circ} \mathrm{C}$. Excess ligand was removed by filtration on a sintered glass filter using distilled water followed by alternate washings with $0.1 \mathrm{M}$ bicarbonate buffer $(\mathrm{pH} 8.0$ ) and $0 \cdot 1 \mathrm{M}$ acetate buffer ( $\mathrm{pH} 4 \cdot 0$ ). Excess groups were blocked by incubation in $50 \mathrm{ml} 1 \mathrm{M}$ ethanolamine overnight. Samples were loaded onto a column $(1 \times 10 \mathrm{~cm})$ containing the fructose/ agarose matrix and washed extensively with column buffer. The fructokinase was eluted with column buffer containing $0.05 \mathrm{M}$ $\mathrm{NaCl}$.

Step 4. Gel filtration. Sephadex G75 (Pharmacia) was used for gel filtration by the method of Curling (1970). Samples were loaded directly onto a column $(2 \times 50 \mathrm{~cm})$ without dialysis, and fractions containing fructokinase activity were pooled and concentrated using Centricon 10 microfiltration cells (Amicon) at 6000 r.p.m. and $4{ }^{\circ} \mathrm{C}$.

SDSPAGE. This was performed by standard procedures (Laemmli, 1970) using the Mini Protean II electrophoresis cell (Bio-Rad). Molecular mass was determined using Dalton Mark VII-L protein mixture (Sigma) as standards. Proteins were detected by staining gels with silver stain (Merril et al., 1981).

IEF. Analytical IEF was performed in IsoGel agarose (FMC Bioproducts) on a Multifor model 2117 flat-bed electrophoresis unit (Pharmacia LKB) using standard procedures (Harper, 1981). Isoelectric point was determined by comparison with IEF standards (Bio-Rad).

$\mathbf{N}$-terminal amino acid sequencing. This was performed by automated Edman degradation using a PI 2090E Integrated Micro-Sequencing System (Porton Instruments). Cysteine residues were detected by the alkylation method of Brune (1992).

\section{RESULTS}

\section{Subcloning of the fructokinase gene (frk) and hybridization analysis}

The cosmid pLA72 was shown to contain the fructokinase gene from Rbizobium leguminosarum bv. trifolii BAL (McLaughlin \& Hughes, 1989). Sau3A fragments (1-3 kb) from pLA72 were subcloned into the Bam HI site of the conjugal vector pRK404 and transferred into the 


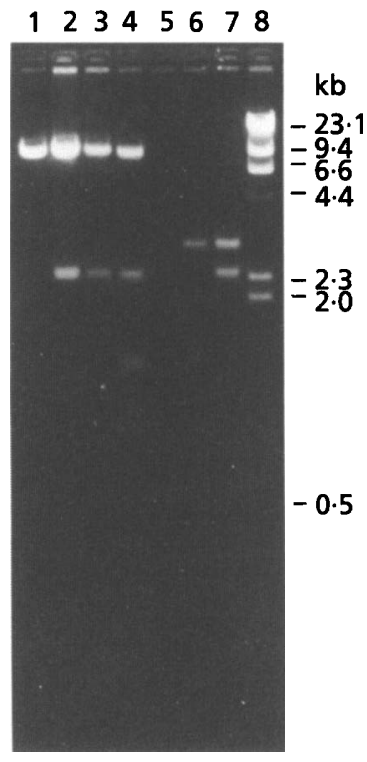

Fig. 1

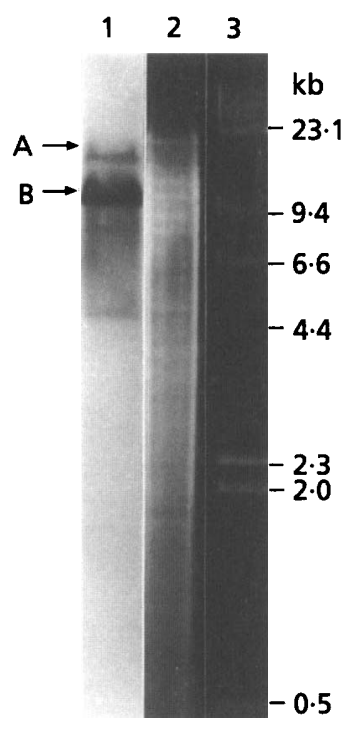

Fig. 2

Fig. 1. Agarose gel $(0.8 \%)$ electrophoresis of BamHI digests of recombinant plasmids. Lane 1, pRK404; lane 2, pB12; lane 3, pB30; lane 4; pB40, lane 6, pBluescriptSK; lane 7, pSK12. Lane 8 , HindIII digest of $\lambda$ DNA (fragment sizes shown on the right). Plasmid DNA was extracted by the alkaline method of Birnboim and Doly (Maniatis et al., 1982) from E. coli DH5 $\alpha$.

Fig. 2. Southern gel analysis of total genomic and plasmid DNA with the $2.4 \mathrm{~kb}$ frk encoding fragment as hybridization probe. Lane 1 shows hydridization of EcoRI-digested DNA of the $R$. leguminosarum bv. trifolii complemented mutant, BAL C79. Lane 2 is C79 EcoRI-digested DNA. Lane 3 is Hindlli-digested $\lambda$ (fragment sizes shown on the right). A, Hybridization to the Tn5-inserted fragment in the chromosome; $B$, hybridization to the intact frk gene on the cosmid pLA72.

Tn 5 mutant, BAL 79, by triparental mating (Ditta et al., 1980). Transconjugants were examined for antibiotic resistance (tetracycline, $12.5 \mu \mathrm{g} \mathrm{ml}^{-1}$ ) indicating the presence of $\mathrm{pRK} 404$, and complementation to give the mucoid phenotype on yeast extract mannitol agar (YEM-KT) since frk mutants have been shown to lack capsule production when grown on medium containing mannitol (McLaughlin \& Hughes, 1989). Kanamycin (150 $\mu \mathrm{g} \mathrm{ml}^{-1}$ ) was used as a counter-selection agent against donor strains. Three clones conferring the mucoid phenotype (pB12, pB30 and pB40) contained the plasmid vector, pRK404, and a $2.4 \mathrm{~kb} \mathrm{BamHI}$ insert (Fig. 1). One clone, pB40, also contained an additional small fragment.

Hybridization analysis of the $2.4 \mathrm{~kb}$ fragment with EcoRIdigested DNA prepared from the complemented mutant, BAL C79, showed that the probe hydridized to the Tn5inserted fragment in the BAL C79 chromosome (Fig. 2, A), as well as to the intact frk gene located on the cosmid, pLA72 (Fig. 2, B) and confirmed that the frk gene isolated was identical to that previously described (McLaughlin \& Hughes, 1989). Hybridization analysis also revealed that the frk gene was located on the $11 \mathrm{~kb}$ EcoRI fragment of pLA72 (data not shown).

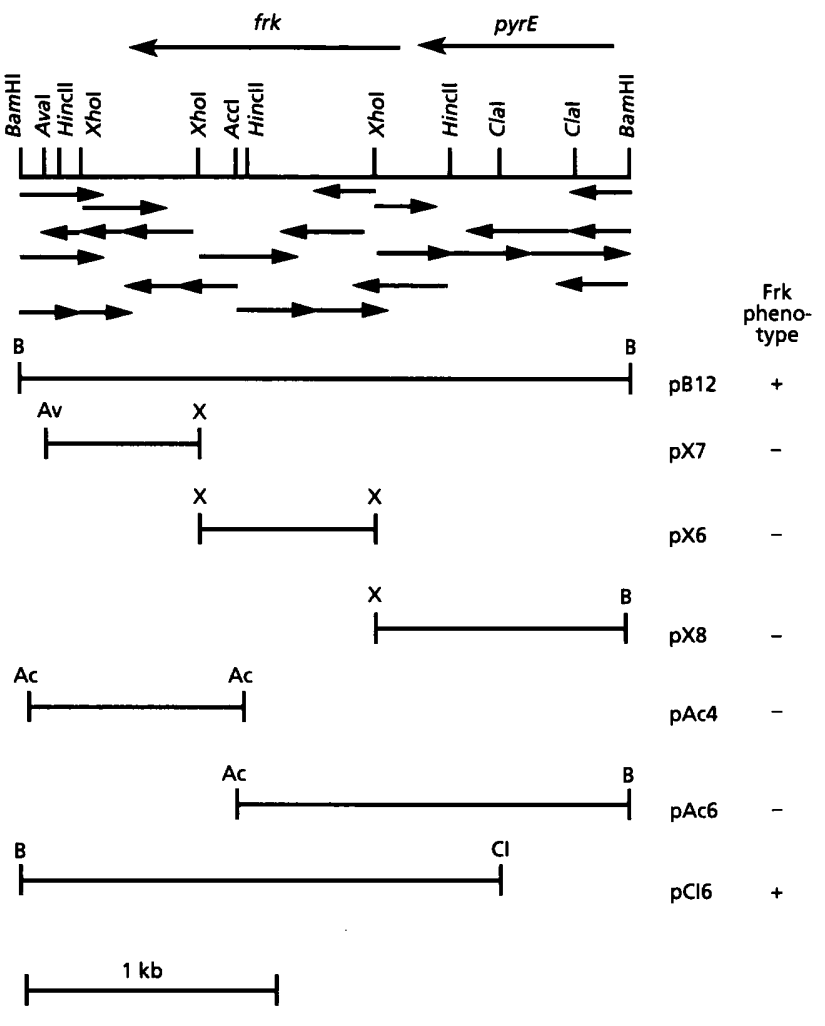

Fig. 3. Restriction map and sequencing strategy for the $R$. leguminosarum bv. trifolii BAL fructokinase gene (frk). The arrow above the restriction map indicates the location and the direction of the ORFs encoding Frk and PyrE. The arrows below the map indicate the location and direction in which the sequence data were read. Subclone analysis and fructokinase activity for each plasmid derivative are shown. $A C, A c C l A v$, Aval; B, BamHI; C, Clal; H, Hincll; X, Xhol.

\section{Gene sequencing}

The $2.4 \mathrm{~kb}$ fragment containing the frk gene was cloned into the Bam HI site of pBluescriptSK and was used for restriction analysis and nucleotide sequencing. Restriction enzyme analysis identified internal AvaI, AccI, ClaI, HincII and $X$ hoI sites (Fig. 3). The fragments resulting from digestion with these enzymes were subcloned into pBluescriptSK and sequenced by the strategy shown in Fig. 3. E. coli $\mathrm{DH} 5 \alpha$ clones containing plasmid derivatives of $\mathrm{pB} 12$ were assayed for fructokinase activity. E. coli $\mathrm{DH} 5 \alpha$ clones containing $\mathrm{pB} 12$ with the intact $2.4 \mathrm{~kb}$ fragment expressed fructokinase activity $\left(0.26 \mathrm{U} \mathrm{mg}^{-1}\right)$; however in $E$. coli $\mathrm{DH} 5 \alpha$ containing pBluescriptSK minimal activity could also be detected $\left(0.003 \mathrm{U} \mathrm{mg}^{-1}\right)$. $E$. coli has been shown to lack a chromosomally encoded fructokinase (Aulkemeyer et al., 1990) and investigators attributed this minimal activity to the presence of a mannokinase which can phosphorylate fructose in the absence of fructokinase. These low levels of activity did not interfere with the detection of cloned fructokinase activity (Sato et al., 1993). No subclones generated using AccI, AvaI, HincII or XboI from the $2.4 \mathrm{~kb}$ fragment and screened in this manner showed fructokinase activity, 
Arg Trp Leu Gly Arg Giu Arg Met Val Ala stop

CGCTGG CTT GGT CGG GAA AGA ATG GTG GCG TAA GTGAGCTITCGCTCTAGCCAGT$-35$ $-10$ SD 871 IGACAAAAGCTCGCCTAATCGGTTGATGAACGTATAGATGCTGTTGGOAGGAATA Met Ile Leu Cys Cys Gly Glu Ala Leu De Asp Met Leu Pro Arg Asp Thr 926 ATG ATT TTG TOC TGC GGC GAA GCC CTG ATC GAC ATG CTG CCG AGO GAC ACC Thr Leu Gly Glu Lys Gly Phe Ala Pro Tyr Ala Gly Gly Ala De Phe Asn 978 ACT CTC GGT GAA AAG GGC TTT GCO CCC TAT GCC GGC GOC GCG ATC TTC AAC Thr Ala lle Ala Leu Gly Arg Leu Gly De Pro Thr Ala Phe Phe Thr Gly ACC GOG ATC GCG CTC GOC CGC CTC GGC ATC CCC ACC GCC TTC TTC ACC OGC Ile Ala Asp Asp Met Met Gly Glu Ile Leu Leu Glu Thr Leu Lys Ala Ser Asn Val Asp Tyr Ser Pro Cys Ala Ile Thr Pro Arg Pro Ser Thr Ile Ala 85 ATC GAT TAC AGC CCG TGC GCC ATT ACG CCG CGT CCC TCG ACC ATC GCC Phe Val Lys Leu Val Asn Gly Gin Ala Thr Tyr Ala Phe Tyr Asp Glu Gly 102 TTC GTC AAG CTO GTO AAC GGC CAA GCG ACC TAT GCC TTC TAC GAC GAG GGC Thr Ala Gly Arg Met Ile Thr Thr Ala Asp Leu Pro Asp Leu Gly Asp Asp 119 ACO GCC GGC CGG ATG ATC ACC ACO GCC GAC CTG CCG GAT CTC GGC GAT GAT Cys Glu Ala Leu His Phe Gly Ala Ile Ser Leu Ile Pro Ser Pro Cys Oly 136 224 TOC GAG OCC TTG CAT TTC OGC GCG ATC AOC CTG ATC CCC AOC CCC TOC.GOC Glu Thr Tyr Glu Ala Leu Leu Asp Arg Glu Ala Ala Ser Arg Val Ile Ser 153 1335 GAA ACC TAC GAA GCC CTG CTC GAC CGC GAA GCC GCA AOC CGC GTC ATC TCG Leu Asp - Pro Asn lle Arg Pro Gly Phe lle Lys Asp Lys Pro Ser His Met 170 1386 CTC GAT CCG AAT ATC COT CCC GGT TTC ATC AAG GAC AAG CCG TCG CAT ATG Ala Arg Ile Lys Arg Met Ala Ala Lys Ser Asp Ile Val Lys Phe Ser Asp 187 Ala Arg De Lys Arg Met Ala Ala Lys Ser Asp lle Val Lys Phe Ser Asp
GCC CGC ATC AAG COC ATO GCC GCC AAA TCC GAC ATC GTC AAG TTC TCC GAC

Glu Asp Leu Asp Trp Phe Gly Leu Gin Gly Asp His Asp Ala Leu Als Ala 204 S8 GAG GAC CTC GAT TGG TTC GOC CTG CAG GOC GAC CAT GAT GCO CTC GCC GCC His Trp Leu Asn His Gly Ala Lys Leu Val Val Ile Thr Lys Gly Ala Giu 221 539 CAT TGG CTO AAC CAC GGC GCC AAG CTC GTC OTC ATC ACC AAG GGC GCO GAA Gly Ala Ser Gly Tyr Thr Lys Asp Arg Lys Val Thr Val Pro Ser Glu Arg 238 590 GOC GCT TCC GGT TAT ACC AAG GAT COC AAG GTC ACG GTG CCG AGT GAA CGG Val Thr Val Val Asp Thr Val Gly Ala Gly Asp Thr Phe Asp Ala Gly lle 255 1641 GTC ACC GTC GTC GAC ACG GTC GGC GCC GGC GAT ACO TTC GAT GCC GGC ATC Leu Ala Ser Leu Lys Met Asp Asn Leu Leu Thr Lys Arg Gin Val Ala Ser 272 1692 CTO GCG TCG CTG AAG ATG GAC AAT CTG CTG ACC AAG COC CAA GTC GCC TCG

Lew Asp Glu Gin Ala Leu Arg Asn Gly Pro Asp Pro Arg Arg Gin Ser Arg 289 1743 CTG GAT GAG CAG GCG CTG CGC AAC GCC CCT GAC CCT COG COC CAA AGC CGC

Arg Arg His Arg Leu Pro Arg Arg Arg Gin Ser Thr Leu Gly Ala Arg Asp 306 49 CGC CGT CAC CGT CTC CCO COC CGO CGC CAA TCC ACC CTO GGC GCO COA GAT

Trp Ser Leu Arg Leu Glu Gln Asp Ser Asp Pro His Pro Pro Asp Asp Thr 323 845 TGG TCT TTA AGG CTC GAG CAA GAC TCC GAC CCT CAT CCG CCT GAC GAC ACC

Phe Ser Pro Stop

1896 TTC TOC CCO TAA ACACGGGGCGAAGGGGATATGCCOCAAACTCTCCGTTCCTCTTGOA transcription terminator

CGTOCAGTATGGAACGTCOCCTCTCCCCGITCTTCACGGGGAGAGGGITAGCGTCATATGCOCTAGGT

Fig. 4. Nucleotide sequence of the frk gene. DNA sequencing was performed as described in Methods. The deduced amino acid sequences are shown above the coding sequences. Putative promoter ( -35 and -10$)$ and ribosome-binding site (SD) complementary to the 16s rRNA are in boldface and doubleunderlined. Inverted repeat sequences are single-underlined.

indicating that these sites were located within the frk gene. Evaluation of the nucleotide sequence of the $2.4 \mathrm{~kb}$ fragment revealed two ClaI sites outside of the frk open reading frame (Fig. 3). Deletion of this $400 \mathrm{bp}$ fragment yielded a plasmid which still retained fructokinase activity $\left(0.24 \mathrm{U} \mathrm{mg}^{-1}\right)$.

The nucleotide sequence of the frk gene and flanking regions are shown in Fig. 4. The sequence was analysed to identify all possible enclosed open reading frames (ORFs). The search revealed two complete ORFs on the reverse strand of the deduced sequence. One (ORF2) was large enough $(978 \mathrm{bp}$ ) for the Frk protein. The start (ATG) codon was at $926 \mathrm{bp}$ and the stop codon (TAA) was at 1904 bp.

Preceding the start codon of the frk gene is a potential ribosome-binding sequence, AGGA, located 6 bp upstream from the ATG initiation codon (Stormo et al., 1982). The sequence contained a putative promoter region (TTGACA-N ${ }_{16}$-GTTGAT) similar to the E. coli consensus promoter (O'Neill, 1989), located 56 bp upstream from the start codon (Fig. 4). A termination sequence was located downstream from the stop codon, from 1971 to
Table 2. Amino acid composition of the $R$. leguminosarum bv. trifolii BAL fructokinase

The data were derived from the ORF 2 gene sequence using the Peptidesort program (Devereux et al., 1984).

\begin{tabular}{|lrr|}
\hline Amino acid & No. & Mol \% \\
\hline Ala & 35 & $10 \cdot 736$ \\
Cys & 5 & $1 \cdot 534$ \\
Asp & 31 & $9 \cdot 509$ \\
Glu & 14 & $4 \cdot 294$ \\
Phe & 12 & $3 \cdot 681$ \\
Gly & 27 & $8 \cdot 282$ \\
His & 7 & $2 \cdot 147$ \\
Ile & 19 & $5 \cdot 828$ \\
Lys & 14 & $4 \cdot 294$ \\
Leu & 32 & $9 \cdot 816$ \\
Met & 8 & $2 \cdot 454$ \\
Asn & 7 & $2 \cdot 147$ \\
Pro & 20 & $6 \cdot 135$ \\
Gln & 7 & $2 \cdot 147$ \\
Arg & 24 & $7 \cdot 362$ \\
Ser & 19 & $5 \cdot 828$ \\
Thr & 22 & $6 \cdot 748$ \\
Val & 14 & $4 \cdot 294$ \\
Trp & 3 & $0 \cdot 920$ \\
Tyr & 6 & $1 \cdot 840$ \\
Mol. mass $=35469$ & & \\
Residues $=326$ & & \\
pI $=5 \cdot 7$ & & \\
\hline
\end{tabular}

1999 bp (d'Aubenton et al., 1990). No other ORFs were identified downstream of frk.

The ORF upstream of the frk gene was identified as the pyrE gene. Characterization of this gene will be reported elsewhere.

\section{Sequence analysis}

The amino acid sequence derived from the translated frk ORF was used to determine the predicted amino acid composition, molecular mass and isoelectric point (Table 2). The frk ORF codes for a putative protein consisting of 326 amino acids with an estimated molecular mass of $35469 \mathrm{Da}$. The predicted isoelectric point is $5 \cdot 7$. The hydropathy plot (Fig. 5) shows that the Frk protein contains mostly hydrophilic amino acid residues, with one area of hydrophobic amino acids (50 residues) at the $\mathrm{N}$ terminus. The predicted amino acid sequence of the Frk protein was assessed for similarity with other known protein sequences. The Frk showed amino acid homology with several kinases, including fructokinases from $S$. typhimurium, $K$. pneumoniae, Salmonella thompson and $V$. alginolyticus, and the ribokinase from E. coli (Aulkemeyer et al., 1991; Blatch et al., 1990; Hope et al., 1986). The Frk 


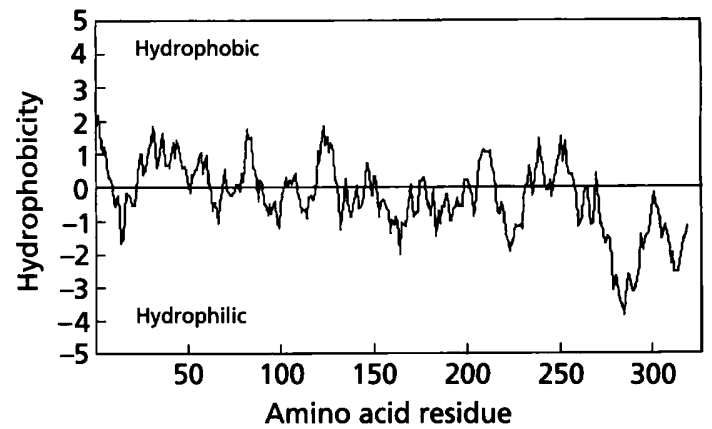

Fig. 5. Hydrophobicity plot of the Frk sequence from $R$. leguminosarum bv. trifolii BAL. The method used was that of Kyte \& Doolittle (1982), with a window size of nine amino acids. Plots were generated using sequence data and the Gene Jockey program (Biosoft).

amino acid sequence shared $28.5 \%$ identity with the $S$. typhimurium fructokinase $(75 / 263)$ and $29 \%$ identity with the $K$. pneumoniae and $V$. alginolyticus fructokinases $(80 / 263)$. Fig. 6 shows regions of homology between these sequences including the $\mathrm{N}$-terminus and regions between residues 158-166, 189-196 and 249-266. These data strongly confirm that the gene identified encodes a fructokinase.

\section{Enzyme purification}

The fructokinase was purified 263 -fold with a $10 \%$ yield using a three-step purification method (Table 3). Inclusion of DTT in all purification buffers was required for enzyme stability. Fructokinases purified from other bacterial sources also required DT'T for enzyme stability during purification ('Thompson et al., 1991, 1992). The plasmidcomplemented mutant, strain B30, expressed higher fructokinase activity $\left(0.27 \mathrm{U} \mathrm{mg}^{-1}\right)$ than the wild-type BAL $\left(0.04 \mathrm{U} \mathrm{mg}^{-1}\right)$ and was used as the source of fructokinase for purification. The cell lysates were subjected to chromatofocusing (Lallan, 1990), and using the narrow-range polybuffer ( $\mathrm{pH} 4-7$ ) the fructokinase eluted at $\mathrm{pH} 4 \cdot 65$. At this step the fructokinase activity was $1.6 \mathrm{U} \mathrm{mg}^{-1}$, representing a purification of 39-fold.

Affinity chromatography has been shown to be an excellent procedure for purification of kinases (Baysdorfer et al., 1989; Dean \& Watson, 1979; Thompson et al.,

\footnotetext{
1

SAL MNAKVWVLGDAVVDLLPE... . SEGRLLQCPGGAPANVAVGVARLGGNSGF IGAVGGDPFGRYMRHTLQQEQVDVSHMYLDDQHRTSTVVVDLDDQGERT

KLEB MNGKIWVLGDAVVDLLPD. . . .GEGRLLQCPGGAPANVAVGVARLGGDSGF IGRVGDDPFGRFMRHTLAQEQVDVNYMRLDAAQRTSTVVVDLDSHGERT

VIB MNQ.VWVTGDAVVDLIPE.... SETSLLKCPGGAPANVAVAIARLSGKSAFFGRVGDDPFGRFMQSI LDQEGVCTEFLIKDPEQRTSTVVVDLDDQGERS

RHIZ ...MILCCGEALIDMLPRDTTLGEKGFAPYAGGAIFNTAIALGRLGIPTAFFTGIADDMMGEILLETLKASNVDYSPCAITPRPSTIAFVKLVNGQA. T

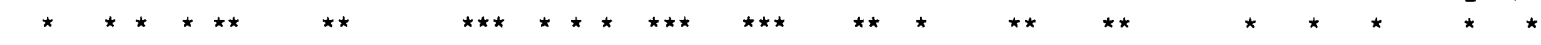

SAL FTFMVRPSADLFLVEEDLPQFAAG. OWLHVCSIALSAEPSRSTTFAAMESIRSAGGFVSFDPNIRPPLWQDQALLLACLDRALHMANVVKLSEEEI 200 KLEB FTFMVRPSADLF LQPEDLPPFAAG. QWLHVCSIALSAEPSRSTTFAALEAIKRAGGYVSFDPNIRSPLWQDPQDLRDCLDRALALA DAIKLSEEEL AFIS VIB FTFMVKP SADQFMSVEDMGNFKQG. DWLHVCSISLANEPSRSSTFEAIKRAKAAGGF ISFDPNIRDEVWODQSEIQAVVMKAVAMA DVVKFSEEEL. LFL RHIZ YAFYDEGTAGRMITTADLPDLGDDCEALHFGAISLIPSPC. GETYEALLDREAASRVISLDPNIRPFF IKDKPSHMARIKRMAAKSDIVKFSDEDLPWFG

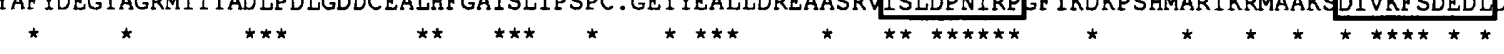

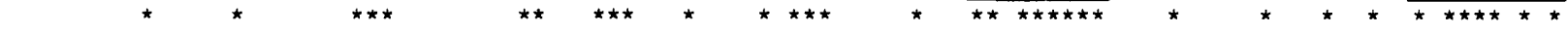

ATP BINDING

SAL SSNDLAYGIASVTERYQPELLLVTRGKAGVLAAFQQKFTHFNARPVASVDTTGAGDAFVAGLLASLAANGMPTDM. TALEPTLTLAQTCGA. . . . . . . KLEB GSDDIVSGIARLNARFQPTLLLVTQGKAGVQAALRGQVSHFPARPVVAVDTTGAGDAFVAGLLAGLAAHGIPDNL. AALAPDLALAQTCGA. . . . . . . VIB TDSTSMAQGLQQ IAAMN IALVLVTQGAKGVWRVFESQSELITGQVVSP IDTTGAGDAFVGGLLACL SRHADWKNH . PVVSSAIQWANGCGA . . . . . . . RHIZ LQGDHD. ALAAHWLNHGAKLVVITKGAEGASGYTKDRKVTVPSEFVTVVDTVGAGDTFDAGILASLKMDNLITKRQVASLDEQALRNGPDPRRQSRRRHR

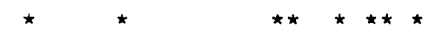

SAL LATTAKGAMTALPYQRDLNRQF.........

KLEB LATTAKGAMTALPYKDDLQRSL.........

VIB LATTGKGAMTALPTOTELLRFIGG . .......

RHIZ LPRRRQSTLGARDWSLRLEQDSDPHPPDDT FSP *

* * *
}

Fig. 6. Multiple alignment of the Frk sequence of $R$. leguminosarum bv. trifolii (RHIZ) with the fructokinases of $S$. typhimurium, K. pneumoniae (SAL, KLEB; Aulkemeyer et al., 1991) and V. alginolyticus (VIB; Blatch et al., 1990). An asterisk indicates an amino acid residue conserved in the rhizobial fructokinase and other fructokinase sequences. Proposed sequences involved in ATP binding and substrate recognition are boxed. 
Table 3. Purification of $R$. leguminosarum bv. trifolii BAL fructokinase

\begin{tabular}{|c|c|c|c|c|c|}
\hline Fraction & $\begin{array}{c}\text { Activity } \\
\left(\mathrm{U} \mathrm{ml}^{-1}\right)^{*}\end{array}$ & $\begin{array}{c}\text { Protein } \\
\left(\mathrm{mg} \mathrm{ml}^{-1}\right)\end{array}$ & $\begin{array}{l}\text { Sp. act. } \\
\left(\mathrm{U} \mathrm{mg}^{-1}\right)^{*}\end{array}$ & $\begin{array}{c}\text { Purification } \\
\text { (-fold) }\end{array}$ & $\begin{array}{c}\text { Yield } \\
(\%)\end{array}$ \\
\hline Crude extract & 0.068 & 1.67 & 0.04 & 1 & \\
\hline Plasmid-enhanced & 0.53 & $2 \cdot 00$ & $0 \cdot 27$ & $6 \cdot 6$ & 100 \\
\hline Chromatofocus & 0.80 & 0.50 & $1 \cdot 60$ & 39 & 30 \\
\hline Affinity chromatography & $1 \cdot 73$ & $0 \cdot 40$ & $4 \cdot 33$ & $104 \cdot 9$ & 13 \\
\hline Gel filtration & $0 \cdot 27$ & $0 \cdot 025$ & $10 \cdot 8$ & $263 \cdot 4$ & 10 \\
\hline
\end{tabular}

* One unit $(\mathrm{U})$ converts $1 \mathrm{mM}$ fructose to fructose 6-phosphate $\mathrm{min}^{-1} \mathrm{ml}^{-1}$ at $\mathrm{pH} 8.0$ at room temperature.

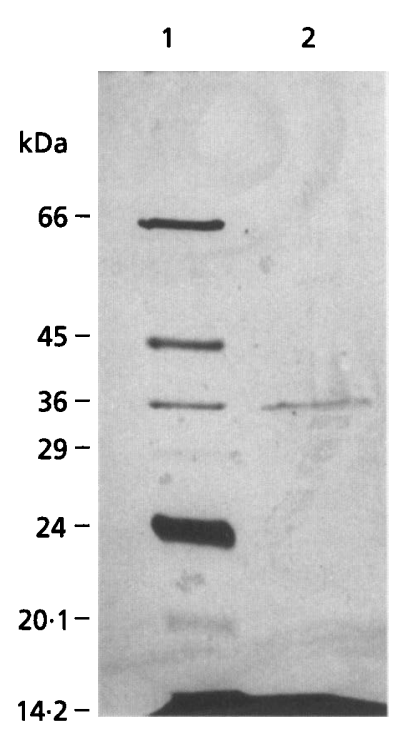

Fig. 7. SDS-PAGE of the purified fructokinase stained with silver. Electrohoresis and gel staining were done by the method of Merril et al. (1981). Lane 1, molecular mass standards (bottom to top): $\alpha$-lactalbumin, trypsin inhibitor, trypsinogen, carbonic anhydrase, glyceraldehyde 3-phosphate, egg albumin, and bovine albumin. Lane 2 , purified fructokinase $(2 \mu \mathrm{g})$.

1991; Vretblad, 1976). However, commercially available matrices previously used for kinase purification (ATPagarose, 5'-AMP-agarose or Cibracron Blue 3GA) either failed to bind the fructokinase or inactivated the enzyme. For these reasons a gel matrix was constructed by linking D-fructose to epoxy-activated agarose. The entire amount of bound fructokinase eluted within two or three fractions and allowed 105-fold purification of the enzyme with $13 \%$ yield.

Electrophoretic homogeneity was achieved by gel filtration using Sephadex G-75. SDS-PAGE analysis of the samples from gel filtration using silver staining (Merril $e t$ al., 1981) identified a single band free of other proteins (Fig. 7). Microsequencing using the alkylation method (Brune, 1992) allowed unambiguous identification of the first $25 \mathrm{~N}$-terminal amino acid residues: Met-Ile-Leu-CysCys-Gly-Glu-Ala-Leu-Ile-Asp-Met-Leu-Pro-Arg-AspThr-Thr-Leu-Gly-Glu-. A comparison of the amino acid sequence from the purified protein with the predicted amino acid sequence from the frk gene indicated that the first 21 amino acids of the fructokinase were identical.

\section{Enzyme characterization}

The molecular mass of the purified fructokinase was determined by SDS-PAGE to be $36.5 \mathrm{kDa}$ (Fig. 7). The purified fructokinase was resolved into a single component by IEF; the isoelectric point was 4.65 (data not shown). The $K_{\mathrm{m}}$ obtained with fructose as substrate was $0.31 \mathrm{mM}$ and the $V_{\max }$ was $31.6 \mu \mathrm{mol}$ fructose 6 phosphate $\min ^{-1}$ (mg protein) ${ }^{-1}$. The $\mathrm{pH}$ range for fructokinase activity was $6 \cdot 0-9 \cdot 0$, with the optimum at $\mathrm{pH} 8.0$. Fructokinase required $\mathrm{Mg}^{2+}$ for activity; omission of $\mathrm{Mg}^{2+}$ resulted in no fructokinase activity. Activity increased with $\mathrm{Co}^{2+}(137 \%)$ as a divalent cation as compared to $\mathrm{Mg}^{2+}$ and activity was also detected with $\mathrm{Cd}^{2+}(35 \%)$ and $\mathrm{Mn}^{2+}(20 \%)$; slight activity was detected with $\mathrm{Ca}^{2+}(3 \%)$. No fructokinase activity was seen with $\mathrm{Ba}^{2+}, \mathrm{Cu}^{2+}, \mathrm{Fe}^{2+}$ or $\mathrm{Zn}^{2+}$.

\section{DISCUSSION}

Fructokinase is an important central metabolic enzyme which has been detected in a variety of rhizobia; it is necessary for the metabolism of mannitol, sucrose and fructose (Duncan, 1981; Glenn et al., 1984; McLaughlin \& Hughes, 1989). It has been shown to be inducible by the inclusion of these substrates in the growth medium as well as repressible by addition of TCA cycle intermediates (Martinez deDrets \& Arias, 1970; Stowers \& Elkan, 1985; Ucker \& Signer, 1978). Although some biochemical research has been done, the rhizobial fructokinase enzyme has not been characterized and the fructokinase gene has not been examined at the molecular level. To our knowledge, this is the first study to report the characterization of the fructokinase enzyme from a Rbizobium species as well as the nucleotide sequence of the fructokinase gene.

Comparison of the fructokinase $R$. leguminosarum bv. trifolii (Frk) amino acid sequence with other known fructokinase sequences shows that it contains two conserved regions. It contains the ATP-binding motif, VDTVGAGDtFdAGiLASL, found in the third family of sugar kinases proposed by Wu et al. (1991), with the critical duo DG essential for activity and coordination of 
the $\mathrm{Mg}^{2+}$ (Heinisch et al., 1989) being conserved. Not only does the $R$. leguminosarum bv. trifolii Frk contain these highly conserved amino acid residues, but the $\mathrm{Mg}^{2+}$ ion has been shown to be essential for the activity of the enzyme. Recently another subfamily of fructokinases has been proposed for the sequences obtained from $S$. mutans (Sato et al., 1993) and Z. mobilis (Zembrzuski et al., 1992). The R. leguminosarum bv. trifolii Frk shows no homology to these two fructokinase sequences, which share $\mathrm{N}$ terminal sequence homology with the protein sequences derived from Lactococcus lactis and Fusobacterium mortiferum (Sato et al., 1993). The R. leguminosarum bv, trifolii Frk does not share this $\mathrm{N}$-terminal sequence homology with these fructokinases, however it does share $\mathrm{N}$-terminal homology with the fructokinases from the $p f k B$ subfamily of sugar kinases, including ribokinase and phosphofructokinase from E. coli (Wu et al., 1991).

In addition to the ATP-binding motif, the $R$. leguminosarum bv. trifolii $\mathrm{Frk}$ also contained two motifs in the second domain of the protein conserved in fructokinases but not in the other sugar kinase of this subfamily (Wu et al., 1991). This middle domain is the proposed substrate recognition site of the sugar kinases (Aulkemeyer $e t$ al., 1991). Although the R. leguminosarum bv. trifolii Frk is only $29-30 \%$ identical to the other fructokinases in this subfamily, the sugar-binding site (residues 110-220) is conserved. These data further confirm this motif as a substrate-specific region.

Hydropathy analysis indicated that the $R$. leguminosarum bv. trifolii Frk is a hydrophilic protein (Fig. 5). This plot differs from plots generated by hydrophobic proteins associated with the bacterial membrane (Kyte \& Doolittle, 1982; Hardesty et al., 1991), which contain long stretches of hydrophobic aminoacyl residues. However, this plot agreed with hydropathy profiles from other fructokinase sequences and reports that fructokinases are typically hydrophilic proteins found in the cytoplasmic fractions (Aulkemeyer et al., 1991).

To date only one other gene involved in carbon metabolism has been identified and sequenced from Rbizobium. Osteras et al. (1991) sequenced the $p c k A$ gene from Rhizobium NGR234 that encodes the phosphoenolpyruvate carboxykinase. This kinase was homologous to the subfamily of sugar kinases (Wu et al., 1991) that contain the class I ATP-binding consensus motif; it shows no homology with the $R$. leguminosarum bv. trifolii Frk sequence. A potential cAMP receptor protein (CRP)binding site regulated by catabolite repression (Osteras $e t$ al., 1991) was not found in the frk gene. Diauxic growth curve studies show that the $R$. leguminosarum bv. trifolii fructokinase is not sensitive to glucose repression (McLaughlin, 1989). In pUR400 and K. pneumoniae, no cAMP-CAP binding site was found and the $s c r K$ genes are not subject to catabolite repression by glucose (Aulkemeyer et al., 1991). Catabolic enzymes in Rbizobium are repressed by succinate (Stowers \& Elkan, 1985; Mandal \& Chakrabartty, 1993). In preliminary studies, fructokinase activity in $R$. leguminosarum bv. trifolii BAL was repressed by growth on succinate as in other thizobia (data not shown).
Fructokinase genes ( $s c r K$ ) from most bacterial sources are commonly located in an operon adjacent to other genes involved in fructose or sucrose metabolism (Aulkemeyer et al., 1991; Blatch et al., 1990; Cowan et al., 1991; Sato et al., 1993). The enzymes encoded by these genes are included in the group II fructokinases. In R. leguminosarum bv. trifolii BAL the gene identified immediately upstream from the frk gene, pyrE, was not involved in hexose metabolism. Since fructokinase genes usually precede or are adjacent to other catabolic genes, this may suggest the absence of a hexose catabolic operon as with the frk gene from Z. mobilis (Zembrzuski et al., 1993). The R. leguminosarum bv. trifolii frk gene was not identified as part of an operon and its product is assigned to the group I fructokinases.

The frk gene sequence contained a putative promoter region located $56 \mathrm{bp}$ upstream from the start codon (TTGACA-N ${ }_{16}$-GTTGAT) (Fig. 4). The proposed promoter contains a -35 region identical to the $E$. coli consensus region, and the -10 region has three out of six bases in common with the $E$. coli consensus sequence and the lac $Z$ promoter (O'Neill, 1989). Surrounding the -35 region is a palindromic sequence capable of stem-loop formation. Palindromic sequences have been implicated as potential binding sites for repressor molecules, as with the repressor of the scr operon, ScrR (Jahreis \& Lengeler, 1993). However, this sequence was determined to be a terminator of the pyrE gene upstream. As in $V$. alginolyticus (Blatch et al., 1990), the terminator of the scr $A$ gene upstream encompasses the proposed -35 region of $s c r K$ gene almost identically to the rhizobial frk gene. Lastly, a terminator sequence was found downstream from the stop codon of the frk sequence, and was consistent with known strong rho-independent terminators in $E$. coli (d'Aubenton et al., 1990).

The molecular mass of the purified fructokinase was determined to be $36500 \mathrm{Da}$ and was in agreement with that predicted from the deduced amino acid sequence of $35473 \mathrm{Da}$. This represents approximately 3\% error, which is lower than usually seen by this type of comparison (Thompson et al., 1991; Wu et al., 1991). The molecular mass was similar to that of other phosphorylating enzymes including fructokinases from $L$. lactis and F. mortiferum (Thompson et al., 1991, 1992), and phosphofructokinases Pfk A and PfkB from E. coli (Wu et al., 1991) and Bacillus stearothermophilus (French \& Chang, 1987), which range from 32 to $35 \mathrm{kDa}$.

The purified fructokinase was resolved to a single band by analytical IEF and the isoelectric point was determined to be 4.65 . These results are identical to those obtained by chromatofocusing, where the fructokinase eluted at $\mathrm{pH}$ 4.65. However, the isoelectric point of the fructokinase predicted by the deduced amino acid sequence was 5.7 (Table 2). These results could differ for a number of reasons. Secondary, tertiary and quaternary structure of the protein contribute significantly to the overall charge of the native protein and this folding of the Frk peptide cannot be easily predicted by computer analysis as can the molecular mass. This emphasizes that all data predicting protein characteristics must be confirmed biochemically. 
Microsequencing of the purified fructokinase showed that the initiator methionine is retained on the mature protein, as for the fructokinases from Z. mobilis (Zembrzuski et al., 1992) and F. mortiferum (Thompson et al., 1992), indicating no post-translational processing of the enzyme as occurs with the fructokinase from L. lactis (Thompson $e t$ al., 1991).

The fructokinase from $R$. leguminosarum bv. trifolii $\mathrm{BAL}$ exhibited many similarities to other fructokinases and kinases. Its $\mathrm{pH}$ range for activity was similar to that of other fructokinases, and like other fructokinases it required divalent cations (McLaughlin \& Hughes, 1989; Sabater \& Delafuente, 1975; Thompson et al., 1991, 1992). Fructokinase activity was increased by the substitution of $\mathrm{Co}^{2+}$ for $\mathrm{Mg}^{2+}$. Other investigators have reported that replacing $\mathrm{Mg}^{2+}$ by $\mathrm{Co}^{2+}$ slightly decreased fructokinase activity (Thompson et al., 1991, 1992). However, the substitution of $\mathrm{Co}^{2+}$ for $\mathrm{Mg}^{2+}$ has been shown to increase phosphoenolpyruvate carboxykinase activity (Podkovyrov \& Zeikus, 1993).

\section{REFERENCES}

d'Aubenton Carafa, Y., Brody, E. \& Thermes, C. (1990). Prediction of rho-independent Escherichia coli transcriptional terminators. $J$ Mol Biol 216, 835-858.

Aulkemeyer, P., Ebner, R., Heilenmann, G., Jahreis, K., Schmid, K., Wrieden, S. \& Lengeler, J. L. (1991). Molecular analysis of two fructokinases involved in sucrose metabolism of enteric bacteria. Mol Biol 5, 2913-2922.

Bach, M. K., Magee, W. E. \& Burris, R. H. (1958). Translocation of photosynthetic products to soybean nodules and their role in nitrogen fixation. Plant Pbysiol 33, 118-124.

Baysdorfer, C., Kremer, D. F. \& Sicher, R. C. (1989). Partial purification and characterization of fructokinase activity from barley leaves. J Plant Physiol 134, 156-161.

Bethlenfalvay, G. J. \& Phillips, D. A. (1977). Photosynthesis and symbiotic nitrogen fixation in Phaseolus vulgaris L. In Genetic Engineering for Nitrogen Fixation, pp. 401-408. Edited by A. Hollaender. New York \& London: Plenum Press.

Blatch, G. L. \& Woods, D. R. (1991). Nucleotide sequence and analysis of the Vibrio alginolyticus scr repressor-encoding gene (scrR). Gene 1010, 45-50.

Blatch, G. L., Scholle, R. S. \& Woods, D. R. (1990). Nucleotide sequence and analysis of the Vibrio alginolyticus sucrose uptakeencoding region. Gene 95, 17-23.

Bradford, M. (1976). A rapid and sensitive method for the quantitation of microgram quantities of protein utilizing the principle of protein-dye binding. Anal Biochem 92, 248-254.

Brockman, J., Heuel, H. \& Lengeler, J. W. (1992). Characterization of a chromosomally encoded, non-PTS metabolic pathway for sucrose utilization in Eschericbia coli EC3132. Mol \& Gen Genet 235, 22-32.

Brune, D. C. (1992). Alkylation of cysteine with acrylamide for protein sequence analysis. Anal Biochem 207, 285-290.

Chein, A., Edgar, D. B. \& Trela, J. M. (1976). Deoxyribonucleic acid polymerase from the extreme thermophile Thermus aquaticus. $J$ Bacteriol 127, 1550-1557.

Cowan, P. J., Nagesha, H., Leonard, L., Howard, J. L. \& Pittard, A. J. (1991). Characterization of the major promoter for the plasmid-encoded sucrose genes $s c r Y, \operatorname{scr} A$ and $s c r B . J$ Bacteriol 173, 7464-7470.

Curling, J. M. (1970). The use of Sephadex in the separation, purification and characterization of biological materials. Exp Pbysiol Biochem 3, 417-484.

Dazzo, F. B. \& Hubbel, D. H. (1975). Cross-reactive antigens and lectin as determinants of symbiotic specificity in the Rbizobiumclover association. Appl Microbiol 30, 1017-1033.

Dean, P. D. G. \& Watson, D. H. (1979). Protein purification using immobilized triazine dyes. J Chromatogr 165, 301-319.

Devereux, J., Haeberli, P. \& Smithies, O. (1984). A comprehensive set of sequence analysis programs for the VAX. Nucleic Acids Res 12, 387-395.

Ditta, G., Stanfield, S., Corbin, D. \& Helinski, D. R. (1980). Broad host range DNA cloning system for Gram-negative bacteria: construction of a gene clone bank of Rbizobium meliloti. Proc Natl Acad Sci US A 77, 7347-7351.

Ditta, G., Schimhauser, T., Yakobson, E., Lu, P., Lang, X. W., Finlay, D. R., Guiney, D. \& Helinski, D. (1985). Plasmids related to the broad host range vector pRK290 useful for gene cloning and for monitoring gene expression. Plasmid 13, 149-153.

Duncan, M. (1981). Properties of $\mathrm{Tn} 5$-induced carbohydrate mutants of Rhizobium meliloti. J Gen Microbiol 122, 61-67.

French, B. A. \& Chang, S. H. (1987). Nucleotide sequence of the phosphofructokinase gene from Bacillus stearothermophilus and comparison with the homologous Escherichia coli gene. Gene 54, 65-71.

Glenn, A. R., Arwas, R., McKay, I. A. \& Dilworth, M. J. (1984). Fructose metabolism in wild-type, frucktokinase-negative and revertant strains of Rbizobium leguminosarum. J Gen Microbiol 119, 267-271.

Hanahan, D. (1983). Studies on transformation of E. coli with plasmids. J Mol Biol 166, 557-580.

Hardesty, C., Ferran, C. \& DiRienzo, J. M. (1991). Plasmid-mediated sucrose metabolism in Escherichia coli: characterization of $\operatorname{scr} Y$, the structural gene for a phosphoenolpyruvate-dependent sucrose phosphotransferase system outer membrane porin. $J$ Bacteriol 173, 449-456.

Harper, D. (1981). Isoelectric focusing in agarose gels. In Electrophoresis '81, Proceedings of the 3rd Conference on Electrophoresis, pp. 205-212. Edited by R. C. Allen \& P. Arnaud. New York: Walter deGruyter.

Heinisch, J., Ritzel, R. G., von Borstel, R. C., Aquilera, A., Rodico, R. \& Zimmermann, F. K. (1989). The phosphofructokinase genes of yeast evolved from two duplication events. Gene 78, 309-321.

Hope, J. N., Bell, A. W., Hermodson, M. A. \& Groarke, J. M. (1986). Ribokinase from Escherichia coli K12: nucleotide sequence and overexpression of the $r b s K$ gene and purification of ribokinase. $J$ Biol Chem 261, 7663-7668.

Jahreis, K. \& Lengeler, J. W. (1993). Molecular analysis of two ScrR repressors and of a ScrR-FruR hydrid repressor for sucrose and Dfructose specific regulons from enteric bacteria. Mol Microbiol 9, 195-209.

Kyte, J. \& Doolittle, R. F. (1982). A simple method for displaying the hydropathic character of a protein. J Mol Biol 157, 105-132.

Laemmli, U. K. (1970). Cleavage of structural proteins during the assembly of the head of bacteriophage T4. Nature 227, 680-685.

Lallan, G. (1990). Chromatofocusing. In Guide To Protein Purification, pp. 380-392. Edited by M. P. Deutscher. San Diego: Academic Press.

Leary, J. J., Brigati, D. J. \& Ward, D. C. (1983). Rapid and sensitive 
colorimetric method for visualizing biotin-labeled DNA probes hybridized to DNA or RNA immobilized on nitrocellulose: Bioblots. Proc Natl Acad Sci US A 80, 4045-4049.

Lineweaver, H. \& Burke, D. (1934). The determination of enzyme dissociation constants. $\mathrm{J} \mathrm{Am} \mathrm{Chem} \mathrm{Soc} \mathrm{56,} \mathrm{658-666.}$

Mandal, N. C. \& Chakrabartty, P. N. (1993). Succinate-mediated catabolite repression of enzymes of glucose metabolism in rootnodule bacteria. Curr Microbiol 26, 247-251.

Maniatis, T., Fritsch, E. F. \& Sambrook, J. (1989). Molecular Cloning: a Laboratory Manual. Cold Spring Harbor N.Y.: Cold Spring Harbor Laboratory.

Martinez deDrets, G. \& Arias, A. (1970). Metabolism of some polyols by Rhizobium meliloti. J Bacteriol 103, 97-103.

McLaughlin, R. E. (1989). PhD thesis, Clemson University.

McLaughlin, R. E. \& Hughes, T. A. (1989). Transposon mutagenesis and complementation of the frucktokinase gene in Rbizobium leguminosarum biovar trifolii. J Gen Microbiol 135, 2329-2334.

Merril, C. R., Goldman, D., Sedman, S. A. \& Ebert, M. H. (1981). Ultrasensitive stain for proteins: polyacrylamide gels show regional variation in cerebrospinal fluid. Science 211, 1437.

O'Neill, M. C. (1989). Escherichia coli promoters. I. Consensus as it relates to spacing class, specificity, repeat substructure, and threedimensional organization. $J$ Biol Chem 264, 5522-5530.

Osteras, M., Finan, T. M. \& Stanley, J. (1991). Site-directed mutagenesis and DNA sequence of pck $A$ of Rbizobium NGR234, encoding phosphoenolpyruvate carboxykinase: gluconeogenesis and host dependent symbiotic phenotype. Mol \& Gen Genet 230, 257-269.

Pate, J. S. (1977). Functional biology of dinitrogen fixation by legumes. In $A$ Treatise on Dinitrogen Fixation, Section III, Biology, pp. 473-518. Edited by R. W. F. Hardy \& W. S. Silver. New York: Wiley-Interscience.

Podkovyrov, M. P. \& Zeikus, J. G. (1993). Purification and characterization of phosphoenolpyruvate carboxykinase, a catalytic $\mathrm{CO}_{2}$ fixing enzyme, from Anaerobiospirillum succiniciproducens. $J \mathrm{Gen}$ Microbiol 139, 223-228.

Ronson, C. W. \& Primrose, S. B. (1979). Carbohydrate metabolism in Rhizobium trifolii: identification and symbiotic properties of mutants. J Gen Microbiol 112, 77-88.

Sabater, B. \& Delafuente, G. (1975). Kinetic properties and related changes of molecular weight in a fructokinase from Streptomyces violaceoruber. Biochim Biophys Acta 377, 258-270.
Sanger, F., Nicklen, S. \& Coulson, A. R. (1977). DNA sequencing with chain terminating inhibitors. Proc Natl Acad Sci USA 78, 4284-4288.

Sato, Y., Yamamato, Y., Kizaki, H. \& Kuramitsu, H. K. (1993). Isolation, characterization and sequence analysis of the $s c r K$ gene encoding fructokinase of Streptococcus mutans. J Gen Microbiol 139, 921-927.

Southern, E. M. (1975). Detection of specific sequences among DNA fragments separated by gel electrophoresis. J Mol Biol 98, 503-517.

Stormo, G. T., Scheider, T. D. \& Gold, L. M. (1982). Characterization of translational initiation sites in E. coli. Nucleic Acids Res 10, 2991-2996.

Stowers, M. D. \& Elkan, G. H. (1985). Regulation of hexose catabolism in Rbizobium sp. 32H1. FEMS Microbiol Lett 26, 45-48.

Thompson, J., Sackett, D. L. \& Donkersloot, J. A. (1991). Purification and properties of frucktokinase I from Lactococcus lactis. $J$ Biol Chem 266, 22626-22633.

Thompson, J., Nguyen, N. Y. \& Robrish, S. A. (1992). Sucrose fermentation by Fusobacterium mortiferum ATCC 25557: transport, catabolism and products. J Bacteriol 174, 3227-3235.

Ucker, D. S. \& Signer, E. R. (1978). Catabolite-repression-like phenomenon in Rhizobium meliloti. J Bacteriol 136, 1197-1200.

Vincent, J. M. (1970). A Manual for the Practical Study of Root-nodule Bacteria (International Biological Programme Handbook no. 15). Oxford: Blackwell Scientific Publications.

Vretblad, P. (1976). Purification of lectins by biospecific affinity chromatography. Biochim Biophys Acta 434, 169-176.

Wu, L., Reizer, A., Reizer, J., Cai, B., Tomich, J. M. \& Saier, M. H., Jr (1991). Nucleotide sequence of the Rbodobacter capsulatus fruK gene, which encodes fructose-1-phosphate kinase: evidence for a kinase superfamily including both phosphofructokinase of Escherichia coli. J Bacteriol 173, 3317-3127.

Zembrzuski, B., Chilco, P., Liu, X., Liu, J., Conway, T. \& Scopes, R. (1992). Cloning, sequencing and expression of the Zymomonas mobilis fructokinase gene and structural comparison of the enzyme with other hexose kinases. $J$ Bacteriol 174, 3455-3460.

Received 17 May 1995; revised 18 September 1995; accepted 20 September 1995. 